\title{
DIVERSIFICATION OF THE FOREIGN TRADE UNDER THE GLOBAL CHANGES
}

\author{
Valentyna Pidhirna \\ Candidate of Economic Sciences \\ Department of Economic Geography and Environmental Management \\ Yuriy Fedkovych Chernivtsi National University \\ 2 Kotsjubynskyi str., Chernivtsi Ukraine, 58012 \\ Oleksandra Chubrey \\ Candidate of Historical Sciences \\ Department of Economic Geography and Environmental Management \\ Yuriy Fedkovych Chernivtsi National University \\ 2 Kotsjubynskyi str., Chernivtsi Ukraine, 58012
}

\begin{abstract}
The article deals with the topical questions, namely, the priorities and challenges that Ukraine faced with on the way to the FTA creation. From the one hand, there were grounded several one-legged trade preferences given to Ukraine. From the other one, there were considered several obstacles that appeared on the way of integration, among them: the combat operations in our country, crisis period without any "universal remedies" for and the other ones.

It was grounded on the base of statistic materials that the main trade partners in European Union according to the results of last years are: Germany, Poland, Italy. But can be seen the optionality of our country in the system of the world economic connections because of the import dependence on the external supplies, as the part of export in the structure of GDP in 2014 reached $47 \%$, import - $55 \%$.

The experience of the country that already passed the stage of integration changes was analyzed, but as we can see on practice it is almost impossible to find the common features of reforms because both Poland and Greece move economy by their own vectors and Ukraine must pay attention to this fact.

It was proved, that to use the competitive advantages for a long time Ukrainian economy must concentrate its activity on the existent natural resources potential, intellectual abilities, industrial development and high technologies.

Keywords: integration, globalization, export, import, services, crisis.
\end{abstract}

\section{Introduction}

The modern foreign economic relations it is a complex of connections that appear both at the level of organizations and enterprises and at the level of states, international organizations and the certain regions that include the different forms of cooperation that develop, improve and complement one another. Undoubtedly, the growing scale and dynamics of the foreign trade, appearance of the new forms and methods conditioned the formation in the XXI century the united system of global regulation of the services and goods exchange, movement of capital, labor forces, experience exchange and the other based on the principles and rules of the World trade organization (WTO), Europe and Eurasian union. Without taking into account the current situation of the world market and its changes it is practically impossible to provide the renewing process in the countries, raise the effectiveness of production, to form the policy of outrunning development of the one sectors of economy and rationalization of the activity of the others.

The global processes that started from the 70-80 years of the XX century continue in the current (XXI) century in the world economy causing the bifurcation restructuring in the world economy and certain dichotomy of the trade flows of the countries because of duality of the countries by the direction of development. All this led to the essential changes in the character of production of the world economic market, international division of labor and conditioned the involvement of the almost all countries of the world into the sphere of international economic changes.

Metamorphose of the processes of formation of competitive advantages of the countries of the world sets for the scientists and politicians the task of theoretical understanding of the regular- 
ities of the influence of the separate national regions on the rise of international competitiveness of the countries and also creation of the effective mechanism of harmonization of the regional and general national interests in the foreign economic sphere that conditions the extreme topicality of the studied problem.

\section{Analysis of the literature data and statement of the problem}

The problem of development of the foreign trade as the factor of expanded reproduction and economic development is rather widely elucidated by both adepts of the severe protectionism [1-2], and representatives of the liberal direction of the foreign trade development [3]. Among the last publications on this topic are worth being separated the works in which the foreign trade influence on the reproductive processes in the economy was considered mainly taking into account the integrative and global aspects of development [4-6]. In which the authors paid attention to the forms of interregional competition, methods of assessment of the international competitive status of the sub-national constructions and also to the problems of formation of the effective regional competitive strategies.

But as the result of the transient changes in the world economy and the necessity of reconstruction of the world economic connections the problem of foreign trade as the factor of the widened reproduction in the Ukrainian economy needs the permanent attention and further studies. Being an important link of the whole process of the world economy functioning it is the determination of the Ukrainian place in the system of international trade connections that is simultaneously the factor of development, mean of the structural reconstruction, institutional modernization and post-industrialization of the national economy.

\section{Object aim and tasks of research}

The object of research is the trade activity of Ukraine with EU countries.

The aim of research is the study of the system of characteristic that determine the regional dynamics and statics in the global economic space in the adaptation period.

For attending the set aim it is necessary solve do the following tasks:

1. To analyze the tendencies of the foreign trade with EU countries for the last years.

2. To study the obstacles that interfere Ukrainian equitable entrance into the European community.

3. To determine the real possibilities for the structural transformations.

\section{Materials and methods of the research}

The use of the system-structural method demonstrated that diversification of the foreign trade plays an important role in the determination of the position of the country on the world market, because the separate states receive the lion's share of income due to the export of goods to the other countries. For today Ukraine has the trade-economic connections with more than 150 countries in the different regions of the Earth with the different scales and effectiveness [7].

The method of comparative analysis was used for argumentation of the possibilities of attainment of institutional convergence through the study of the experience of the countries that joined the European community much earlier than Ukraine and on this base must be formed the own program of structural transformations.

To reveal the causes of "blocking" of the market-institutional changes and acquire the concrete practical decisions for reducing the import dependence of Ukraine on the external loans was used the cliometric method.

\section{The results of research}

For the end of 2014 Ukraine occupied the 22-th place among the trade partners of European Union forming 1,1\% Bof the total volumes of the foreign trade of EU. Analyzing the dynamics of two-sided trade for 2011-2014 it must be noted the growth of the EU part in the Ukrainian foreign trade of services and goods from $29,6 \%$ to $32,1 \%$. The main trade partners of Ukraine in European 
Union were: Germany (18,5 \% of GGC in EU), Poland (13,4 \%) and Italy (9\%), this information is graphically presented on the Fig. 1.

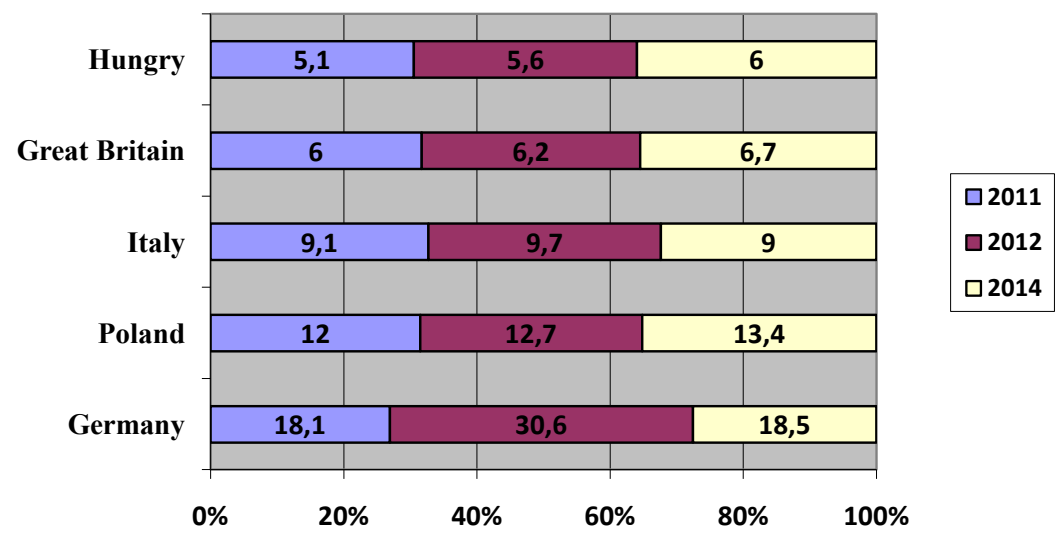

Fig.1. The main trade partners of Ukraine in EU for 2011-2014 Source: completed by the author base on the data [8]

Despite the fact that Germany occupies the first positions among the countries-trade partner of Ukraine by the volume of GGC, the main part of Ukrainian export goes to Poland (in particular, fuel, raw material and half-finished products, machines, industrial and transport equipment, cloth and household goods) and Italy (in particular: machines, equipment, tissues, fruits, vegetables, textiles, cloth, goods made of leather, motors, electrical goods, chemicals, marble) while Germany stays a leader in supply of the goods and services into Ukraine [9]. In 2014 our country intensified the cooperation with the other country of EU, especially France and Netherland in the trade of goods, especially chemical and petroleum production and also the transport equipment are in demand in our country.

But as to disposition (determination of the place) of the our country in the system of world economic connections and IDL the objective assessment of situation does not allow consider Ukraine to be ready to the involvement in the world economic space on a parity basis, because the part of export in the structure of GDP in 2014 reached $47 \%$, import - $55 \%$, in fact we can see the import dependence of our country on the external supplies, but it would not be a problem, if we do not export the raw material and import the ready goods. As we can see in the aspect of goods export can be observed its extremely ineffective character directed on the raw material, Fig. 2.

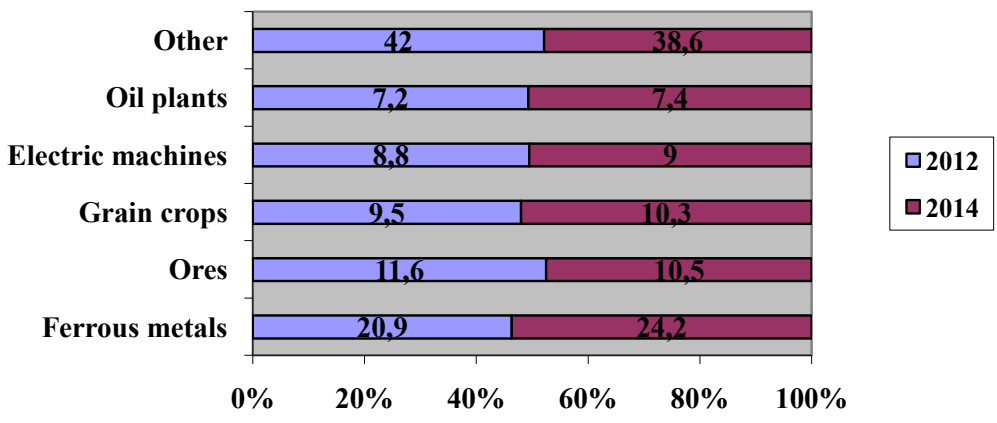

Fig.2. Export structure of the goods for 2012-2014

Source: completed by the author on the base of data [10]

As to the export of services for the same period to the EU countries, the largest part was consisted of the transport ones $(65,7 \%)$, different business, professional and technical services $(12,7 \%)$, and repair ones $(4,5 \%)$, Fig. 3 . 


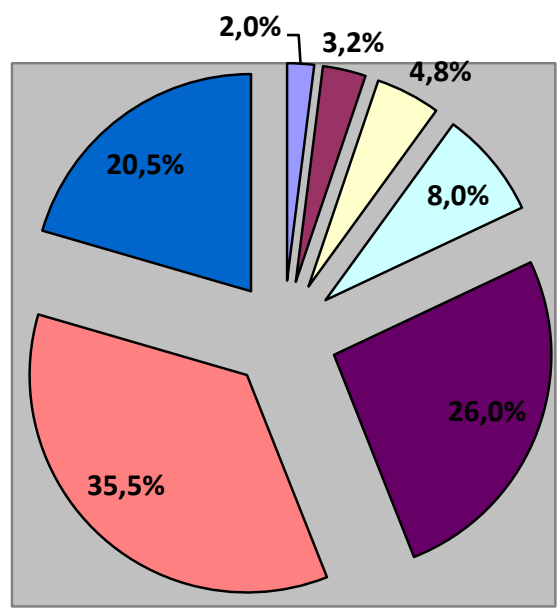

$\square$ Repair services
$\square$ Building services
$\square$ Royalty
$\square$ Computer services
$\square$ Transport services
$\square$ Financial services
$\square$ Other services

Fig.3. The specific structure of export of the services to EU countries for 2011-2014 Source: completed by the author on the base of data [9]

Last time there took place the growth of the part of computer state services and repair services but it is much less than the part of import of these services from EU countries [4]. The study of the foreign trade of services and goods from the positions of its specific structure proved the extensive character of development of the native non-material sphere, because the part of innovative services both in import and export of Ukrainian services is insignificant.

The three leaders of oil and gas industry according to the results of the first half of the year are: NAC "Naftogas of Ukraine", "WOG Trading", "OKKO-Business", we do not go into details about the property of these objects. In 1998 was made a decision to centralize under the state all purchase and distribution of the natural gas within Ukraine that is why NAC "Naftogas of Ukraine" was created. Since this time the company is the largest importer of gas. No private company exceeds the import indices of this state company for today [11].

The absence in Ukraine of the sufficient amount of the coking coal puts Ukraine in dependence on this kind of raw material and makes this metallurgy direction one more classic leader of import. "Alchevsk metallurgy combine", "Avdeevka Coke and Chemical factory", we must also note the pharmacy, especially, LTD "BaDM" that realizes distribution by supplying in our country the wide assortment of remedies [10]. Obviously, Kyiv and Kyiv region is the most import oriented region. The indices of Dnipro region stay practically stable and Donetsk one that is in the epicenter of combat actions leaved the list of leaders of import consumption.

The specific weight of the European Union countries in the import of goods in 2015 comparing with the 1 half of 2016 did not change and is $35,4 \%$ from the total volume, from the other countries $-64,6 \%$, at the same time the import of goods increased only from Belarus $(+14,8 \%)$, and decreased from the other largest countries-partners. In the import structure the main shortening of volumes took place at the expense of mechanical engineering production, metallurgy, chemical industry.

So, despite the intensity of supplies and sufficient indices, at characterizing the structure of import operations, we must note that its base in 2011-2015 was formed by the production with the low technological mode, first of all, planting, mineral resources and also the raw materials with the low level of technological processing. The last 20 years they formed the main part of incomes of the state budget of the country and proceeds from its sale determined the state costs of internal and external programs.

Frankly saying, the absence in the native economy of the model of stimuli necessary for the innovative development objectively determines the disadvantaged and peripheral place and role of Ukraine, diminishing the possibilities to participation in strategically high effective types on the basis of the full partnership. The obvious proof of this fact is the orientation of the native industry on the production and export of goods of III and IV technological modes that were already exhausted in the developed countries already in the middle 1970-ies. According to the III $(57,9 \%)$ and 
IV (38,2 \%) technological modes is produced more than $96 \%$ of industrial production in Ukraine. The ferrous metallurgy, electric power industry, railway transport, inorganic chemicals and so on are exported by the state (according to the III industrial mode) [5].

In the structure of import the production of $\mathrm{V}$ mode, especially: electric equipment, computing equipment, telecommunications, information services which production in Ukraine is only $13,1 \%$. It is also worth noting that only $4,5 \%$ of investment are spent on production of this group of goods.

On the base of aforesaid data can be proved the orientation of so-called old industrial regions of Ukraine on the external sales markets of their production - metal and steel [12]. For today the four of five tones of metal produced in Ukraine goes for export. But because of the prolonged recession in European Union Ukraine loses its arterial sales market of metal and must be reoriented on the countries of Near East, Northern Africa and India. As the result it loses the favorable geographic positioning in prospect.

Then it loses also the other competitive advantages: first of all, access to the cheap iron ore, coking coal and surely to the cheap natural gas. But the problem is in the fact, that the markets that Ukraine reorients on are not stable. So, in Arabian countries in the near 5 years is prognosticated the reconstruction of energetic powers for 50 million tones of production for one year, steel export from China in 2012 raised more than in 2,3 times. The character features of the modern stage of "necroindustrialism" in Ukraine are not only the unprofitableness of the more than half of industrial enterprises but also the critical level of wear and obsolescence of the main funds [6, 13].

As the proof, the foreign trade of Ukraine with EU countries was characterized with the negative trade balance, stability of the part of the native export to the European Union. At the same time it must be noted that the part of goods import from EU increased and part of services import gradually decreased. The main characteristics of two-sided foreign trade flows, like earlier, are the export oriented on the raw materials and high technological export. The specialists saw the possibility to change this situation in singing the Association agreement.

As practice shows, integration is the significant threat for the significant part of mankind causing the division of countries into the "civilization center" and "peripheral zone", deepening their differentiation in the socio-economic development.

Ukraine extremely needs for the stable growth of economy and increase of well-being of people and plans to attain this aim on the way to European integration. We want to analyze the experience of two countries that passed the way of integrative transformation. On the one hand, the experience of the European integration of Poland that is very important for Ukraine because after the breakdown of communist system both countries were in the familiar start conditions. At the same time we know that Poland went to EU during 13 years - from association in 1991 to the entrance in 2004. At the start of integrative processes the situation was in many aspects familiar to the one of Ukraine: skepticism of the Western countries and resistance of Russian, presence of the foreign army on the territory of Poland, the low level of public support of the idea of entrance to NATO and EU, fear of losing independence and so on [6]. The important factor of European integration of Poland was the Weimar triangle - the specific format of cooperation between Poland, Germany and France. Their support gave it the great advantage. It was mainly political advantage, when Western states seriously assured Poland that it will be a member of EU despite of everything. At the same time this support gave Poland the great financial inflows due to the union programs, especially - PHARE.

The most significant were the direct subsidies from the EU budget. It came to Poland within realization of the two priorities of EU, especially, the policy of alignment and support of agriculture. In total since entrance to EU (1 of May, 2004) it has got near 85,3 billions of euro. According to the directions within the policy of alignment were get 52,8 billions of euro and within the common agricultural policy - 28,2 billions. Only in 2012 Poland has got near 12 "net" billions of euro from the EU budget.

It must be noted one more time that the named sums entered to the budget and were spent for the financing of directions that corresponded to the names of operative programs. At the same time the greatest part of funds it is the capital costs that could not be directed on the other aims. 
So, the significant volume of EU costs is directed on modernization of the infrastructure of Poland (buildings of motorways, airports, modernization of railways, renovation of the park of municipal transport); realization of energy-efficient arrangements (from the development of projects of the "green" energetics to re-equipment of TPP on gas consumption); on SCW support; small business development; financing of education and science and so on.

From the other side it becomes obvious, that the successes of European integration are not so significant that is conditioned by the certain problems of integrative character [6]. After acquiring the membership in EU the economy of Greece for the first 10 years hardly made two ends meet: the GDP growth in the period from 1981 to 1990 was only $0,7 \%$ and was three times lower than in EU-15. For today Greece undergoes the more economic decline, than after its entrance to EU, even the write-off of the part of debts by the European community did not help. The situation with the state debts worsened in the CEE countries: from the beginning of crisis it increased from 38 to $49 \%$ of GDP and in Hungry - to $80 \%$ and already exceeded the Maastrihtsky criterion. It is typical, that in EU countries with the higher level of the state debt to GDP had the higher deficit of state budget. Practically the debt crisis mainly conditioned the budget one, increase of the state debts and decrease of GDP growth [12].

Where can we find the solution? The answer is simple. For today in the fight with the modern economic crisis in Europe many governments rely not on the recommendations of classics but on the recipes of IMF shortening the state costs and investment programs, decreasing the demand and driving economy into recession $[3,13]$. That is why we want to pay the special attention to the employment problem that appears just after the reforms and cannot be solved by the shortening of the state costs.

As practice shows, unemployment not only has the negative impact on the economy interrupting its growth but also demoralize people. This point of view is appreciated by the most famous scientists noting that in Ukraine, unfortunately, is no proper attention to the unemployment problem $[5,7]$.

Let us return to the arrairs of our country. The current 2014 year is the year of great attainments and great losses for Ukraine. From the one hand, the Revolution of dignity eliminated the pro-Russian regime of Yanukovich that stopped the movement of Ukraine to Europe, fast degraded and acquired the features of dictatorship. Then the Agreement of Ukrainian association with EU was signed and ratified. The preterm elections of president and Parliament that changed the authorities were realized.

The native economy had significant losses. But they were a result not only of the external aggression but first of all of the systemic deformation that were accumulated for a long time, absence of the basic conditions for the stable economic development.

\section{Discussion of the results of analysis}

So, the analysis allows establish the weak points in the sphere of structural features of development of the foreign trade of Ukraine both in geographic and marketable aspect. The increase of the import dependence of the country is also the great problem.

The solution of the problem of development of the foreign trade as the factor of widened reproduction and modernization of the national economy in general is in rationalization of the foreign economy connections, not in increase but in decrease of the export quote, in the change of material-raw material and value content of import and export and also, if possible, their mutual equilibration. For optimization of the export structure it is necessary to elaborate the export strategy that presupposes the creation of correspondent economic and institutional conditions.

That is why the prospective researches in this direction must be oriented on the assessment of institutional aspects of development of the foreign trade, concretization of the separate components structural and institutional analysis, detection of the causal relationship of the problems of the foreign trade development.

\section{Conclusions}

As the results of researches:

1. Ukraine wants to realize itself in the geopolitical space in the context of the world civilization development, to determine its priorities, real national interests, strategy and tactics of its 
realization, and elaborate such line of foreign policy that from the one side, would be correspondent to the general tendencies of the modern world development and from the other one - favor the realization of the own national interests, growth of the own authority and influence on the international affairs in a best way.

2. For this we must not forget, that the main aim of the state policy of foreign economy is in the creation of conditions for formation of the long-term competitive advantages in native commodity producers. Because in addition to the fact that taxes and social payments in Ukraine are rather high for economy of the transition period with unstable and not strong market relations, they are unified for the all payers whether it is a multi-millionaire or small entrepreneur who hardly survives. For using the competitive advantages for the long period Ukrainian economy must concentrate its activity on: "for now" existing natural resources potential, existing work force, industrial development, potential advantages for the high technologies development and so on. But there are only potential advantages, they must be developed.

3. For support of the effective demand in the country and stimulation of the investment program of development the state must realize the active and timely regulating policy. For this aim must be used the creation of state unprofitable credit-financial institutions for realization of the development projects. For avoiding the inflation growth the resources must be involved into circulation for creation of the real value. At the same time such approach would favor the decrease of the interest rates. The open and public activity of all these institutions under the social control will create the "islands" of uncorrupted relations that is very important for country that is sinking in corruption. The aforesaid approach can be used in "crisis-integrative" period for Ukraine for reproducing the elements of the market infrastructure. Realization of this recipe would allow also involve the many billions of money resources of population of the country that are beyond the economy.

\section{References}

[1] Siebert, H. (2007). The world Economy. A global analysis, Routledge, Abingdon, Great Britain, 369.

[2] Nelson, R. (1996). The evolution of competitive or comparative advantage, International Institute for Applied Systems Analysis, Laxenburg, Austria, 38.

[3] Krugman, P. (2012). End this depression now! New York and London, 259.

[4] Lukianenko, D. G. (2006). Management of the international competitive advantages under the conditions of economic development globalization, Kyiv: KNEU, 816.

[5] Andriichuk, V. G. (2013). Dichotomy of intensive cure and progressive dynamism of global economy and disposition of Ukraine in the system of international economic relations. Foreign trade, economics, finance, law, 3, 5-18.

[6] Nikolenko, S. (2014). The concept of sustainable development at global level as the embodiment of the idea of a world power, Economic theory, 4, 5-16.

[7] Gonchar, I. A. (2013). Nature of establishing foreign trade of Ukraine: statistical assessment. Statistics of Ukraine, 2, 16-27.

[8] Eurostat (2014). Luxembourg: Office for Official Publications of the European Communities. Available at: http://ec.europa.eu/eurostat

[9] Official web-site of the State Statistics Service of Ukraine (2014). Quality of trade activity. Available at: http://www.ukrstat.gov.ua/

[10] Official web-site of the State Statistics Service of Ukraine (2014). The Association Agreement between Ukraine and the European Union. Available at: http://www.ukrstat.gov.ua/

[11] Forbes Ukraine (2014). Top-25 exporters of Ukraine: Forbes ranking. Available at: http://forbes. ua/ua/business/1384704-top-25-eksporteriv-ukrayini-renking-forbes

[12] Cabinet of Ministers of Ukraine (2013). On approval of the list of goods, the import and export of which subject to licensing, and quotas for 2014, 243, 11-12.

[13] Keynes, J. M. (1936). The General Theory of Employment, Interest and Money, Macmillan, London, 263. 